\title{
Histone H2B Type W-T
}

National Cancer Institute

\section{Source}

National Cancer Institute. Histone H2B Type W-T. NCI Thesaurus. Code C162843.

Histone H2B type W-T (175 aa, 20 kDa) is encoded by the human H2BW1 gene. This protein may play a role in male germ cell differentiation and nucleosome assembly. 